\title{
Can such an animal model truly represent Henoch-Schönlein purpura?
}

\author{
Fengying Wang ${ }^{1,2} \cdot$ Ruyue Chen ${ }^{1} \cdot{\text { Xiaozhong Li }{ }^{1} \cdot \text { Yunyan Shen }}^{1}$
}

Received: 7 March 2018 / Accepted: 26 April 2018 / Published online: 14 May 2018

c) Springer-Verlag GmbH Germany, part of Springer Nature 2018

\section{Dear Editor,}

We read the article entitled "Histopathological and immunological changes during the acute and recovery phase in Henoch-Schönlein purpura rabbit model" published in Arch Dermatol Res with great interest [3]. Animal models are of great value in studying the pathogenesis of diseases. Literature on Henoch-Schönlein purpura (HSP) animal models is scarce; therefore, we consider that researches on exploring Henoch-Schönlein purpura animal model are very valuable.

Although the work they did makes a great contribution to the research on HSP models, the model needs to be further improved to truly represent Henoch-Schönlein purpura.

There are some key issues that need to be explored in the paper, which is critical to the success of the model. It has become the consensus that Henoch-Schönlein purpura, now called IgA vasculitis, is a kind of leukocyte rupture vasculitis mediated by immunoglobulin A-dominant immune complex affecting small vessels, and often involves skin, gastrointestinal tract, joints, and kidney [2].

Firstly, whether there was IgG and IgM deposition in skin and kidney tissue had not been explored. They only detected the deposition of IgA and C3, which was seen in the method section in the article "... and immunofluorescence staining was used for the detection of $\operatorname{Ig} \mathrm{A}$, and $\mathrm{C} 3$ in the skin and kidney with specific antibodies (anti rabbit IgA-FITC, anti rabbit C3-FITC, MP-cappel)." Therefore, the study was not

This comment refers to the article available at https://doi. org/10.1007/s00403-016-1694-z.

An author's reply to this comment is available at https://doi. org/10.1007/s00403-018-1839-3.

Xiaozhong Li

1xzsuzhou@outlook.com

1 Department of Nephrology and Rheumatology, Children's

Hospital of Soochow University, Jingde Street 303,

Suzhou 215000, Jiangsu, China

2 Department of Pediatrics, Affiliated Taixing Hospital of Yangzhou University, Taixing, Jiangsu, China able to determine whether $\operatorname{IgA}$ deposition was predominated among three immunoglobulin (IgG, $\operatorname{Ig} A$, $\operatorname{IgM})$, then nor was it possible to determine whether the model was an HSP model.

In the second place, the skin lesion of the model animal was caused by local irritation of the skin, rather than spontaneous purpura-like skin lesions as HSP patients, so it was not able to simulate the spontaneous clinical manifestations of HSP.

In addition, the majority of experimental animal species do not express IgA receptor Fc $\alpha$ RI, which omits the effects of neutrophil activation via Fc $\alpha$ RI [1]. So, it is not clear whether these models are representatives to study the pathomechanisms of HSP.

\section{References}

1. Heineke MH, Ballering AV, Jamin A, Ben MS, Monteiro RC, Van Egmond M (2017) New insights in the pathogenesis of immunoglobulin a vasculitis (Henoch-Schonlein purpura). Autoimmun Rev 16:1246-1253

2. Jennette JC, Falk RJ, Bacon PA, Basu N, Cid MC, Ferrario F, Flores-Suarez LF, Gross WL, Guillevin L, Hagen EC, Hoffman GS, Jayne DR, Kallenberg CG, Lamprecht P, Langford CA, Luqmani RA, Mahr AD, Matteson EL, Merkel PA, Ozen S, Pusey CD, Rasmussen N, Rees AJ, Scott DG, Specks U, Stone JH, Takahashi K, Watts RA (2013) 2012 revised international chapel hill consensus conference nomenclature of vasculitides. Arthritis Rheum 65:1-11

3. Li Y, Sui X, Zhu H, Xu Y, Huang L, Xu Y, Han Y, Feng X, Qin C (2017) Histopathological and immunological changes during the acute and recovery phase in Henoch-Schonlein purpura rabbit model. Arch Dermatol Res 309:21-30 